\title{
THE EFFECT OF CURRENT RATIO, DEBT TO ASSETS RATIO AND WORKING CAPITAL TURNOVER ON RETURN ON ASSSETS IN PLASTIC COMPANIES AND PACKING LISTED ON INDONESIA STOCK EXCHANGE
}

\author{
Dedek Kurniawan Gultom ${ }^{1}$, Bahril Datuk ${ }^{2}$, Mei Indriani ${ }^{3}$ \\ Universitas Muhammadiyah Sumatera Utara \\ E-mail: dedekkurniawan@umsu.ac.id
}

\begin{abstract}
This research was conducted with the aim of knowing the effect of the Current Ratio, Debt to Assets Ratio and Working Capital Turnoveron Return On Assets in plastic and packaging companies listed on the Indonesia Stock Exchange. The population in this study is all plastic and packaging company listed on the Indonesia Stock Exchange while the sample that meets the criteria for sampling observations carried out for seven years and as many as six yearsplastic and packaging company listed on the Indonesia Stock Exchange. This research approach uses associative research.Data collection techniques in this study using documentation techniques. cand the analysis technique used is multiple linear regression analysis, hypothesis testing and coefficient of determination. The results showed that the independent variables in this study had a simultaneous effect on Return On Assets. While the partial test proves the Cuirrent Ratio variable has a significant effect on Return On Assets, while partially proves the Debt to Assets Ratio variable andWorking Capital Turnover does not have a positive effect on Return On Assets in plastic and packaging companies listed on the Indonesia Stock Exchange.
\end{abstract}

Keywords: Return On Assets, Current Ratio, Debt to Assets Ratio, Working Capital Turnover

\section{PRELIMINARY}

The company was established with the aim of increasing the value of the company so that it can provide prosperity for the owners or shareholders and the company. With the increasing size of the company developing to be able to follow and meet changing market needs and obtain the best capable management, then one of the company's achievement goals is to always maximize profits.(Gultom, 2017).

Therefore, the company's management in practice is required to be able to meet the targets set by the company, namely obtaining maximum profits that can be measured using profit ratios or profitability ratios.(Rambe, 2013).

Return On Assetsshows the company's ability to use all of its assets to generate aftertax profits. This ratio is important for the management to evaluate the effectiveness and efficiency of the company's management in managing all company assets. The greater the ROA, the more efficient the use of company assets or in other words the same number of assets can produce greater profits, and vice versa.(Julita, 2008). Return on Assets (ROA) is a ratio that measures the company's ability to obtain net income from the amount of funds invested by the company or the company's total assets.(Gultom et al., 2020)

International Journal of Educational Review, Law And Social Sciences |IJERLAS

E-ISSN: 2808-487X | https://radjapublika.com/index.php/IJERLAS 
The Effect Of Current Ratio, Debt To Assets Ratio And Working Capital Turnover On Return On Asssets In Plastic Companies And Packing Listed On Indonesia Stock Exchange

Dedek Kurniawan Gultom, Bahril Datuk, Mei Indriani

The following is net profit data for plastic and packaging companies listed on the Indonesia Stock Exchange.

Table 1.1 Net Profit Data on Plastic and Packaging Companies Listed on the Indonesia Stock Exchange (In Millions)

\begin{tabular}{|c|c|c|c|c|c|c|c|c|}
\hline \multirow{2}{*}{$\begin{array}{c}\text { Company } \\
\text { Code }\end{array}$} & \multicolumn{7}{|c|}{ Year } & \multirow[b]{2}{*}{ Average } \\
\hline & 2014 & 2015 & 2016 & 2017 & 2018 & 2019 & 2020 & \\
\hline AKPI & $34,659,623$ & $27,644,714$ & $52,393,857$ & $13,333,970$ & $64,226,271$ & $54,355,268$ & 66.005 .547 & $44,659,893$ \\
\hline APP & $9,691,077$ & $1,854,275$ & $12,909,670$ & $-1,329,429$ & $-23,496,671$ & $9,588,681$ & $-1,691,876$ & 1.075 .104 \\
\hline IGAR & $55,155,279$ & $51,416,184$ & $69,305,630$ & $72,376,683$ & $44,672,438$ & $60,836,753$ & $60,770.710$ & $59,219,097$ \\
\hline IMPC & 289798712 & 129759076 & 125823131 & 91303492 & 105523929 & 93145200 & $115,805,394$ & $135,879,848$ \\
\hline TALF & $57,889,730$ & $33,717,726$ & $30,137,707$ & $21,465,837$ & $43,976,734$ & $22,702,989$ & $19,234,714$ & $32,732,205$ \\
\hline TRST & $30,256,039$ & $25,314,103$ & $33,794,867$ & $38,199,682$ & $63,193,899$ & $38,911,968$ & $41,843,234$ & $38,787,685$ \\
\hline Average & 79.575 .077 & $44,951,013$ & $54,060,810$ & $39,225,039$ & $49,682,767$ & 46.590 .143 & $50,327,954$ & $52,058,972$ \\
\hline
\end{tabular}

Source : Indonesia Stock Exchange (2021)

Based on table 1.1 above, it can be seen that the average net profit of plastic and packaging companies listed on the Indonesia Stock Exchange is IDR 52,058,972. If you look at the average every year, there are 2 years above the average and 5 years below the average where 2 years are above the average, namely in 2014 amounting to Rp79,575,077 in 2016 amounting to Rp54,951,013 and 5 years below the average, namely in 2015 of Rp. 44,951,954, in 2017 of Rp. 39,225,039 in 2018 of Rp. 56,590,954 in 2019 of Rp. 46,590,143 and in 2020 of Rp. 50,327,954. Based on the previous description, it can be concluded that the net profit of plastic and packaging companies listed on the Indonesia Stock Exchange on average has decreased every year.

The following is net profit data for plastic and packaging companies listed on the Indonesia Stock Exchange.

Table 1.2 Data on Total Assets in Plastic and Packaging Companies Listed on the Indonesia Stock Exchange (In Millions)

\begin{tabular}{|c|c|c|c|c|c|c|c|c|}
\hline \multirow{2}{*}{$\begin{array}{c}\text { Compa } \\
\text { ny Code }\end{array}$} & \multicolumn{7}{|c|}{ Year } & \multirow[b]{2}{*}{ average } \\
\hline & 2014 & 2015 & 2016 & 2017 & 2018 & 2019 & 2020 & \\
\hline AKPI & $\begin{array}{r}2,227,042,5 \\
90 \\
\end{array}$ & $\begin{array}{r}2.883 .143 .1 \\
32 \\
\end{array}$ & $\begin{array}{r}2,615,909,1 \\
90 \\
\end{array}$ & $\begin{array}{r}2,745,325,8 \\
33 \\
\end{array}$ & $\begin{array}{r}3,070,410,4 \\
92 \\
\end{array}$ & $\begin{array}{r}2,776,775,7 \\
56 \\
\end{array}$ & $\begin{array}{r}2,664,267,7 \\
16 \\
\end{array}$ & $\begin{array}{r}2,711,839,2 \\
44 \\
\end{array}$ \\
\hline APP & $273.126,658$ & $308,620,387$ & 382.461 .777 & $398,698,780$ & 503.177 .499 & $419,264,529$ & $388,847,649$ & $382,028,183$ \\
\hline IGAR & $350,619,527$ & $383.936,041$ & $439,465,673$ & $513,022,592$ & $570,197,811$ & $617,594,781$ & $665,863,417$ & $505.814,263$ \\
\hline IMPC & $\begin{array}{r}1,209,092,5 \\
05 \\
\end{array}$ & $\begin{array}{r}1,675,232,6 \\
85 \\
\end{array}$ & $\begin{array}{r}2,276.031 .9 \\
22 \\
\end{array}$ & $\begin{array}{r}2,294,677,4 \\
93 \\
\end{array}$ & $\begin{array}{r}2,370,198,8 \\
18 \\
\end{array}$ & 2501132856 & $\begin{array}{r}2,697,100.0 \\
62 \\
\end{array}$ & $\begin{array}{r}2,146,209,4 \\
77 \\
\end{array}$ \\
\hline TALF & $433,975,363$ & 434.210 .377 & $881,673,022$ & $921,240,989$ & $984,597,772$ & $\begin{array}{r}1,107,547,3 \\
37\end{array}$ & $\begin{array}{r}1,441,389,1 \\
32\end{array}$ & $886,376,285$ \\
\hline TRST & $\begin{array}{r}3,261,285,4 \\
95\end{array}$ & $\begin{array}{r}3,357,359,5 \\
00\end{array}$ & $\begin{array}{r}3,290,596,2 \\
24\end{array}$ & $\begin{array}{r}3,332,905,9 \\
36 \\
\end{array}$ & $\begin{array}{r}4,284,901,5 \\
87\end{array}$ & $\begin{array}{r}4,349,022,8 \\
88 \\
\end{array}$ & $\begin{array}{r}4,477,691,3 \\
07\end{array}$ & $\begin{array}{r}3,764,823,2 \\
77\end{array}$ \\
\hline Average & $\begin{array}{r}1,292,523,6 \\
90 \\
\end{array}$ & $\begin{array}{r}1,507,083,6 \\
87 \\
\end{array}$ & $\begin{array}{r}1,647,689,6 \\
35 \\
\end{array}$ & $\begin{array}{r}1,700,978,6 \\
04 \\
\end{array}$ & $\begin{array}{r}1,963,913.9 \\
97 \\
\end{array}$ & $\begin{array}{r}1,961,889,6 \\
91 \\
\end{array}$ & $\begin{array}{r}2,055,859,8 \\
81 \\
\end{array}$ & $\begin{array}{r}1,732,848,4 \\
55 \\
\end{array}$ \\
\hline
\end{tabular}

Source : Indonesia Stock Exchange (2021)

Based on table 1.2 above, it can be seen that the average total assets of plastic and packaging companies listed on the Indonesia Stock Exchange is Rp.1,732,848,455. If you look at the average every year, there are 3 years above the average and 4 years below the average where 3 years are above the average, namely in 2018 of Rp. 1,963,913,997 in 2019 of Rp. 1 $.961,889,691$ in 2020 amounted to Rp 2,055,859,881 and 4 years below the average, namely in 
2014 amounted to $\mathrm{Rp} 1,292,523,690$, in 2015 amounted to $\mathrm{Rp}$ 1,507,083687, in 2016 amounted to $\operatorname{Rp} 1,647,689,635$ in 2017 amounted to IDR 1,700,978,604.

The following is the current asset data for plastic and packaging companies listed on the Indonesia Stock Exchange.

Table 1.3 Data on Total Current Assets in Plastic and Packaging Companies Listed on the Indonesia Stock Exchange (In Millions)

\begin{tabular}{|c|c|c|c|c|c|c|c|c|}
\hline \multirow{2}{*}{$\begin{array}{c}\text { Company } \\
\text { Code }\end{array}$} & \multicolumn{7}{|c|}{ know } & \multirow[b]{2}{*}{ average } \\
\hline & 2014 & 2015 & 2016 & 2017 & 2018 & 2019 & 2020 & \\
\hline AKPI & 920.128 .174 & $1,015,820,277$ & $870,146,141$ & 1.003 .030 .428 & $1,233,718,090$ & $1,087,597,237$ & $910,024,936$ & $1,005,780,755$ \\
\hline APP & $89,509,389$ & 81.119 .627 & $95,591,354$ & $126,404,953$ & $201,923,603$ & $123,669,639$ & $278,780,868$ & $142,428,490$ \\
\hline IGAR & 302.146 .093 & $309.534,957$ & $361,504,736$ & $396,252,893$ & $416,191,470$ & $446,573,796$ & $509,735,319$ & $391,705,609$ \\
\hline IMPC & $1,209,092,505$ & $897,761,063$ & $1,261.952 .056$ & $1,200,668,597$ & $1,220,137,554$ & 1174699544 & $1,261,952,159$ & $1,175,180,497$ \\
\hline TALF & 302.876 .054 & $306.262,235$ & $325,494,162$ & $351,255,637$ & $405,988,724$ & $460,092.190$ & $610,661,944$ & $394,661,564$ \\
\hline TRST & $1,182,292,915$ & $1,137,766,718$ & $1,179,999,892$ & $1,189,727,025$ & $1,494,150,559$ & $1,394,497,850$ & $1,458,826,268$ & $1,291,037,318$ \\
\hline Average & $667,674,188$ & $624,710,813$ & $682,448,057$ & $711,223,256$ & $828,685,000$ & $781,188,376$ & $838,330,249$ & $733,465,706$ \\
\hline
\end{tabular}

\section{Source : Indonesia Stock Exchange (2021)}

Based on table 1.3 above, it can be seen that the average total assetlancer in plastic and packaging companies listed on the Indonesia Stock Exchange is IDR733,465,706. If you look at the average every year, there are 3 years above the average and 4 years below the average where 3 years are above the average, namely in 2018 of IDR 828,685,000 in 2019 of IDR $781,188,376$. in 2020 of Rp838,330,249and 4 years below the average, namely in 2014 of Rp667,674,188in 2015 amounted to Rp624,710,813, in 2016 amounted to Rp682,448,057 in 2017 amounted to Rp711,223,256. Based on the previous description, it can be concluded that the total current assets of plastic and packaging companies listed on the Indonesia Stock Exchange on average have decreased every year.

The following is current debt data on plastic and packaging companies listed on the Indonesia Stock Exchange.

Table 1.4 Data on Total Current Debt in Plastic and Packaging Companies Listed on the Indonesia Stock Exchange (In Millions)

\begin{tabular}{|l|r|r|r|r|r|r|r|r|}
\hline \multirow{2}{*}{$\begin{array}{c}\text { Company } \\
\text { Code }\end{array}$} & 2014 & 2015 & 2016 & 2017 & 2018 & 2019 & 2020 & current debt \\
\cline { 2 - 9 } & average \\
\hline AKPI & $812,876,508$ & 985.625 .515 & $770,887,902$ & $961,284,302$ & $1,215,369,846$ & $1,003,137,696$ & $879,913,552$ & $947,013,617$ \\
\hline APP & $31,090,309$ & $68,835,517$ & $60,079,243$ & $73,638,952$ & $201,327.227$ & $87,957,257$ & $86,184,468$ & 87.016 .139 \\
\hline IGAR & $73,319,695$ & $62,393,967$ & $62,350,882$ & $60,941,267$ & $72,223,978$ & $57,853,675$ & $48,639,860$ & $62,531,903$ \\
\hline IMPC & $581,900,349$ & $395,268,301$ & 334.534 .009 & 333.004 .594 & $342,328,902$ & 479079545 & $608,353,619$ & $439,209,903$ \\
\hline TALF & $82,021,759$ & $69,980,727$ & 111.360 .301 & $127,673,270$ & 151.341 .882 & $169,162,412$ & $218,970,463$ & $132,930,116$ \\
\hline TRST & $955,175,793$ & $869,536,724$ & $909,779,314$ & $968,421,072$ & $1,314,074,890$ & $1,300,374,327$ & $1,219,826,342$ & $1,076,741,209$ \\
\hline Average & $422,730,736$ & $408,606.792$ & 374.831 .942 & 420.827 .243 & $549,444,454$ & $516,260,819$ & $510,314,717$ & $457,573,815$ \\
\hline
\end{tabular}

\section{Source : Indonesia Stock Exchange (2021)}

Based on table 1.4 above, it can be seen that the average total current debt of plastic and packaging companies listed on the Indonesia Stock Exchange is Rp.457,573,815If you look at the average every year there are 3 years above the average and 4 years below the average where 3 years are above the average, namely in 2020 of Rp.510,314,717, in 2018 it was 
The Effect Of Current Ratio, Debt To Assets Ratio And Working Capital Turnover On Return On Asssets In Plastic Companies And Packing Listed On Indonesia Stock Exchange

Dedek Kurniawan Gultom, Bahril Datuk, Mei Indriani

Rp549,444,454 in 2019 it was Rp516,260,819 and 4 years below the average, namely in 2014 of Rp.422,730,736, in 2015 amounted to Rp408,606,792, in 2016 amounted to Rp 374,831,942 in 2017 amounted to Rp420,827,243. decrease.

The following is the total debt data on plastic and packaging companies listed on the Indonesia Stock Exchange.

Table 1.5 Data on Total Debt in Plastic and Packaging Companies Listed on the Indonesia Stock Exchange (In Millions)

\begin{tabular}{|l|r|r|r|r|r|r|r|r|}
\hline \multirow{2}{*}{$\begin{array}{c}\text { Company } \\
\text { Code }\end{array}$} & \multicolumn{10}{|c|}{ Year } & \multicolumn{1}{|c|}{$\mathbf{2 0 1 8}$} \\
\cline { 2 - 9 } & $\mathbf{2 0 1 4}$ & \multicolumn{1}{|c|}{$\mathbf{2 0 1 5}$} & \multicolumn{1}{c|}{$\mathbf{2 0 1 6}$} & \multicolumn{1}{c|}{$\mathbf{2 0 1 7}$} & $\mathbf{2 0 1 9}$ & \multicolumn{2}{c|}{$\mathbf{2 0 2 0}$} & \multicolumn{1}{c|}{ average } \\
\hline AKPI & $1,195,437,301$ & $1,775,577,239$ & $1,495,874,021$ & $1,618,713,342$ & $1,836,576,739$ & $1,531,819,965$ & $1,330,380,657$ & $1,540,625,609$ \\
\hline APP & $48,553,667$ & $87,059,306$ & $116.726,058$ & $171,514.782$ & $298,992,622$ & $206.523,459$ & $179,279,616$ & $158,378,501$ \\
\hline IGAR & $86,443.556$ & $73,471,782$ & $65,716,638$ & $71,075,842$ & $87,283,567$ & $80,669,409$ & $72,281,042$ & $76,705,977$ \\
\hline IMPC & $751,768,302$ & $578,352,730$ & $1,050,386,739$ & $1,005,656,524$ & $997,975,487$ & 1092845023 & $622,838,614$ & $871,403,346$ \\
\hline TALF & $114,720,263$ & $84,008,353$ & $129,777,537$ & 155.076 .157 & $176,218,785$ & 310.574 .143 & $414,870.020$ & $197,892,180$ \\
\hline TRST & $1,504,845,098$ & $1,400,438,810$ & $1,358,241,040$ & $1,357,336,439$ & $2,047,516,971$ & $2,174,561,951$ & $2,114,884,360$ & $1,708,260,667$ \\
\hline Average & $616,961,365$ & $666,484,703$ & $702,787,006$ & $729,895,514$ & $907,427,362$ & $899,498,992$ & $789,089,052$ & $758,877,713$ \\
\hline
\end{tabular}

Source : Indonesia Stock Exchange (2021)

Based on table 1.5 above, it can be seen that the average total debt to plastic and packaging companies listed on the Indonesia Stock Exchange is Rp758,877,713. If you look at the average every year there are 3 years above the average and 4 years below the average where 3 years are above the average, namely in 2018 of Rp. 907,427,362 in 2019 of Rp. 899,498,992. in 2020 of Rp789,089,052and 4 years below the average, namely in 2014 of Rp616,961,365, in 2015 amounted to Rp666.484,703, in 2016 amounted to Rp 702,787,006 in 2017 amounted to Rp729,895,514. Based on the previous description, it can be concluded that the total debt of plastic and packaging companies listed on the Indonesia Stock Exchange on average has decreased every year.

The following is data on total sales of plastic and packaging companies listed on the Indonesia Stock Exchange.

Table 1.6 Total Sales Data on Plastic and Packaging Companies Listed on the Indonesia Stock Exchange (In Millions)

\begin{tabular}{|c|c|c|c|c|c|c|c|c|}
\hline \multirow{2}{*}{$\begin{array}{c}\text { Compa } \\
\text { ny Code }\end{array}$} & \multicolumn{7}{|c|}{ Year } & \multirow[b]{2}{*}{ average } \\
\hline & 2014 & 2015 & 2016 & 2017 & 2018 & 2019 & 2020 & \\
\hline AKPI & $\begin{array}{r}1,945,383,03 \\
1 \\
\end{array}$ & $\begin{array}{r}201746651 \\
1 \\
\end{array}$ & $\begin{array}{r}204721863 \\
9 \\
\end{array}$ & $\begin{array}{r}206485764 \\
3 \\
\end{array}$ & $\begin{array}{r}238742003 \\
6 \\
\end{array}$ & $\begin{array}{r}225112329 \\
9 \\
\end{array}$ & $\begin{array}{r}223011309 \\
3 \\
\end{array}$ & $\begin{array}{r}213479746 \\
5 \\
\end{array}$ \\
\hline APP & $294,081.114$ & 260667212 & 347205836 & 382238397 & 438050806 & 437990210 & 233175758 & 341915619 \\
\hline IGAR & 737863227 & 677331846 & 792794835 & 761926952 & 777316507 & 776541441 & 739402296 & $\begin{array}{r}751882443 . \\
4\end{array}$ \\
\hline IMPC & 1413257059 & $\begin{array}{r}114783837 \\
9 \\
\end{array}$ & $\begin{array}{r}113529619 \\
2 \\
\end{array}$ & $\begin{array}{r}119305443 \\
1 \\
\end{array}$ & $\begin{array}{r}139529881 \\
5 \\
\end{array}$ & $\begin{array}{r}149575970 \\
1 \\
\end{array}$ & $\begin{array}{r}179751487 \\
7 \\
\end{array}$ & $\begin{array}{r}136828849 \\
3 \\
\end{array}$ \\
\hline TALF & $558,080,193$ & 476383634 & 56941993 & 646087885 & 741056148 & 924654058 & 771274415 & $\begin{array}{r}669565189 . \\
4\end{array}$ \\
\hline TRST & $\begin{array}{r}2,507,884,79 \\
7\end{array}$ & $\begin{array}{r}245734944 \\
5\end{array}$ & $\begin{array}{r}224941884 \\
7\end{array}$ & $\begin{array}{r}235493801 \\
6\end{array}$ & $\begin{array}{r}263091855 \\
8\end{array}$ & $\begin{array}{r}256609474 \\
8\end{array}$ & $\begin{array}{r}221450598 \\
8\end{array}$ & $\begin{array}{r}242587291 \\
4\end{array}$ \\
\hline Average & $\begin{array}{r}1,242,758,23 \\
7\end{array}$ & $\begin{array}{r}1,172,839,5 \\
05\end{array}$ & $\begin{array}{r}1,190,225,7 \\
24\end{array}$ & $\begin{array}{r}1,233,850,5 \\
54\end{array}$ & $\begin{array}{r}1,395,010,1 \\
45\end{array}$ & $\begin{array}{r}1,408,693,9 \\
10\end{array}$ & $\begin{array}{r}1,330,997,7 \\
38 \\
\end{array}$ & $\begin{array}{r}1,282,053,6 \\
87\end{array}$ \\
\hline
\end{tabular}

\section{Source : Indonesia Stock Exchange (2021)}

Based on table 1.6 above, it can be seen that the average total sales of plastic and packaging companies listed on the Indonesia Stock Exchange is Rp1,282,053,687If you look at the average every year there are 3 years above the average and 4 years below the average where 3 years are above the average, namely in 2018 it was Rp. 1,395,010,145 in 2019 it was 
Rp. Rp1,408,693,910, in 2020 it was Rp1,330,997,738and 3 years below the average, namely in 2014 of Rp1,242,758,237in 2015 amounted to Rp1,172,839,505, in 2016 amounted to Rp1,190,225,724 in 2017 amounted to Rp1,233,850,554. Based on the previous description, it can be concluded that the total sales of plastic and packaging companies listed on the Indonesia Stock Exchange on average have decreased every year.

The following is data on total working capital for plastic and packaging companies listed on the Indonesia Stock Exchange.

Table 1.7 Data on Total Working Capital of Plastic and Packaging Companies Listed on the Indonesia Stock Exchange (In Millions)

\begin{tabular}{|c|c|c|c|c|c|c|c|c|}
\hline \multirow{2}{*}{$\begin{array}{c}\text { Compan } \\
\text { y Code }\end{array}$} & \multicolumn{7}{|c|}{ Year } & \multirow[b]{2}{*}{ average } \\
\hline & 2014 & 2015 & 2016 & 2017 & 2018 & 2019 & 2020 & \\
\hline AKPI & 107.251.666 & $30,194,762$ & $99,258,239$ & 41.746 .126 & $18,348,244$ & $84,459,541$ & $30,111,384$ & $58,767,137$ \\
\hline APP & $58,419,080$ & $12,284.110$ & $35,512,111$ & 52.766 .001 & 596,376 & $35,712,382$ & $\begin{array}{r}192,596,40 \\
0 \\
\end{array}$ & $55,412,351$ \\
\hline IGAR & $228,826.398$ & $\begin{array}{r}247,140,99 \\
0 \\
\end{array}$ & $\begin{array}{r}299,153,85 \\
4 \\
\end{array}$ & $\begin{array}{r}335,311,62 \\
6 \\
\end{array}$ & $\begin{array}{r}343,967,49 \\
2 \\
\end{array}$ & $\begin{array}{r}388,720,12 \\
1 \\
\end{array}$ & $\begin{array}{r}461,095,45 \\
9 \\
\end{array}$ & $\begin{array}{r}329,173,70 \\
6 \\
\end{array}$ \\
\hline IMPC & $627,192.156$ & $\begin{array}{r}502,492,76 \\
2 \\
\end{array}$ & $\begin{array}{r}927,418,04 \\
7 \\
\end{array}$ & $\begin{array}{r}867,664,00 \\
3 \\
\end{array}$ & $\begin{array}{r}877,808,65 \\
2 \\
\end{array}$ & $\begin{array}{r}695,619,99 \\
9 \\
\end{array}$ & $\begin{array}{r}653,598,54 \\
0 \\
\end{array}$ & $\begin{array}{r}735,970,59 \\
4 \\
\end{array}$ \\
\hline TALF & $220,854.295$ & 236.281508 & $\begin{array}{r}214,133,86 \\
1 \\
\end{array}$ & $\begin{array}{r}223,582,36 \\
7 \\
\end{array}$ & $\begin{array}{r}254,646.84 \\
2 \\
\end{array}$ & $\begin{array}{r}290.929 .77 \\
8 \\
\end{array}$ & $\begin{array}{r}391,691,48 \\
1 \\
\end{array}$ & $\begin{array}{r}261,731,44 \\
7 \\
\end{array}$ \\
\hline TRST & 227.117 .122 & $\begin{array}{r}268,229,94 \\
4 \\
\end{array}$ & $\begin{array}{r}270,220,57 \\
8 \\
\end{array}$ & $\begin{array}{r}221,305,95 \\
3 \\
\end{array}$ & $\begin{array}{r}180,075.66 \\
9 \\
\end{array}$ & $94,123,523$ & $\begin{array}{r}238,999,92 \\
6 \\
\end{array}$ & $\begin{array}{r}214.296 .10 \\
9 \\
\end{array}$ \\
\hline Average & 244.943 .453 & $\begin{array}{r}216.104 .02 \\
1 \\
\end{array}$ & $\begin{array}{r}307,616,11 \\
5 \\
\end{array}$ & $\begin{array}{r}290,396,01 \\
3 \\
\end{array}$ & $\begin{array}{r}279,240,54 \\
6 \\
\end{array}$ & $\begin{array}{r}264.927 .55 \\
7 \\
\end{array}$ & $\begin{array}{r}328,015,53 \\
2 \\
\end{array}$ & $\begin{array}{r}275,891,89 \\
1 \\
\end{array}$ \\
\hline
\end{tabular}

\section{Source : Indonesia Stock Exchange (2021)}

Based on table 1.7 above, it can be seen that the average total working capital of plastic and packaging companies listed on the Indonesia Stock Exchange is Rp.275,891,891. If you look at the average every year, there are 4 years above the average and 3 years below the average where 4 years are above the average, namely in 2016 of IDR 307,616,115 in 2017 of IDR 290,396,013 in 2018 it was IDR 279,240,546, in 2020 it was IDR 328,015,532 and 3 years below the average, namely in 2014 it was IDR244.943.453in 2015 amounted to IDR $216,104,021$ in 2019 amounted to IDR 264,927,55557. Based on the previous description, it can be concluded that the total working capital of plastic and packaging companies listed on the Indonesia Stock Exchange on average has increased every year.

\section{LITERATURE REVIEW \\ Return On Assets}

Return on assetsable to measure the company's ability to generate profits in the past and then projected in the future. Assets or assets in question are all company assets obtained from own capital or from foreign capital which have been converted by the company into company assets that are used for the survival of the company.

(Rambe et al., 2015) states "Return on assets reflects how much return is generated on every rupiah of money invested in assets". (Fahmi, 2014)states that "The ratio of return on investment (ROI) or return on investment that in some other references this ratio is also written as return on total assets (ROA). This ratio looks at the extent to which the investment that has been invested is able to provide a return of profit as expected. and the investment is actually the same as the company's assets that are invested or placed". 
The Effect Of Current Ratio, Debt To Assets Ratio And Working Capital Turnover On Return On Asssets In Plastic Companies And Packing Listed On Indonesia Stock Exchange Dedek Kurniawan Gultom, Bahril Datuk, Mei Indriani

Whereas (Brigham \& Houston, 2014)states "The ratio of net income to total assets measures the return on total assets (ROA) after interest and taxes." The greater the return on assets (ROA), it means the more efficient the use of company assets or in other words with the same number of assets, greater profits can be generated, and vice versa.

\section{Current Ratio}

The current ratio is a ratio to measure the company's ability to pay short-term obligations or debts that are due soon with available current assets.(Munawir, 2010)states that "Current Ratio is a comparison between current assets and current liabilities. This ratio shows that the value of current assets (which can immediately be converted into money) is several times short-term debt. This current ratio also shows the level of security of short-term creditors or the company's ability to pay these debts, but a high current ratio does not necessarily guarantee that the company's debts are due because the proportion or distribution of current assets is not profitable.

(Cashmere, 2017)states that "Current Ratio is a ratio to measure the company's ability to pay short-term obligations or debts that are due immediately when they are billed as a whole. In other words, how much current assets are available to cover short-term obligations that will soon mature.(S Hani, 2015) stated "Current Ratio is a tool for the ability of liquidity (shortterm solvency), namely the ability to pay debts which must immediately be met with current assets".

Whereas(Jumingan, 2017)states that "Currnet Ratio is a ratio that is commonly used in financial statement analysis because the Current Ratio provides a rough measure of the company's liquidity level. Current Ratio is obtained by dividing current assets (current liabilities).

From the above understanding, it can be concluded that the Current Ratio (CR) is a ratio that assesses the extent to which the company pays its short-term obligations by comparing current assets and current liabilities. Current Ratio (CR) is a company's ability to pay its current debt which is assessed from current assets owned, where current assets mean wealth or cash that can be used to cover the company's debts.

\section{Debt to Assets Ratio}

Debt to Assets Ratio is a ratio that measures how much assets are financed with debt. The higher the ratio, the greater the risk faced by the company. DAR is calculated by dividing total debt (liability) by total assets. This ratio is used to measure how much assets are financed with debt. The higher the ratio, the greater the assets financed with debt and it is more risky for the company.(S Hani, 2015) states that "Debt to Assets Ratio, which is a ratio that calculates what part of the total funding needs are financed with debt".

(Cashmere, 2017)states that "Debt to Assets Ratio (DAR) is a debt ratio used to measure the ratio between total debt and total assets. In other words, how much of the company's assets are financed by debt or how much the company's debt affects asset management(Sudana, 2015)states that: "Debt to Assets Ratio or Debt Ratio is one of the leverage ratios that shows how much the company's financing is financed by debt. DAR measures the proportion of funds sourced from debt to finance company assets. The greater the DAR, the greater the portion of the use of debt in financing investment in assets, which means that the company's risk will also increase.

So the conclusion of the Debt to Assets Ratio is to show the total amount of debt that can be guaranteed by total assets or to show the amount of funds provided by creditors to the 
total assets owned by the company. The higher the Debt To Assets Ratio, the greater the company's risk because debt causes a fixed interest expense to the company.

\section{Working Capital Turnover}

Working capital has an important relationship with the daily operating conditions of the company, because working capital is used to meet the company's short-term needs, thus working capital must be managed properly, in order to maintain its business smoothly.(Munawir, 2010) stated that: "working capital turnover to assess the effectiveness of working capital can be used working capital turnover ratio".

(Cashmere, 2017)say that :

"Working capital turnover is one of the ratios to measure or assess the effectiveness of the company's working capital during a certain period. If the working capital turnover is low, it means that the company is having excess working capital. Whereas(Jumingan, 2017) said that "if the volume of sales increases investment in inventories and receivables also increases this means also increasing working capital".

Thus, it can be concluded that working capital turnover is a ratio used to measure the effectiveness of working capital in a company and shows how many sales (in rupiah) the company can get for each rupiah of working capital during a certain period. Low working capital turnover due to high working capital embedded in receivables

\section{RESEARCH METHODS}

This study uses empirical data obtained from the Indonesia Stock Exchange (www.idx.co.id) which focuses on plastic and packaging companies listed on the Indonesia Stock Exchange and the data taken is from 2014 to 2020. The IDX office address in Medan is located at Jl. New Juanda No. 5-6A, Medan.

The research time is planned from January 2021 to May 2021.

The population is a group that has similarities in one or several things that form the main problem in a study. according to(A Juliandi et al., 2015) population is the totality of all elements in the research area.

The population used in this study were all plastic and packaging companies listed on the Indonesia Stock Exchange in 2014-2020, totaling 16 companies.

\section{RESEARCH RESULTS AND DISCUSSION T-Test Results (Partial Test)}

The $t$ test used in this study was used to determine the ability of each independent variable. Another reason is that the t-test is conducted to test whether the independent variable (X) partially or individually has a significant relationship or not to the dependent variable (Y).

Table 4.1. $t$ test results

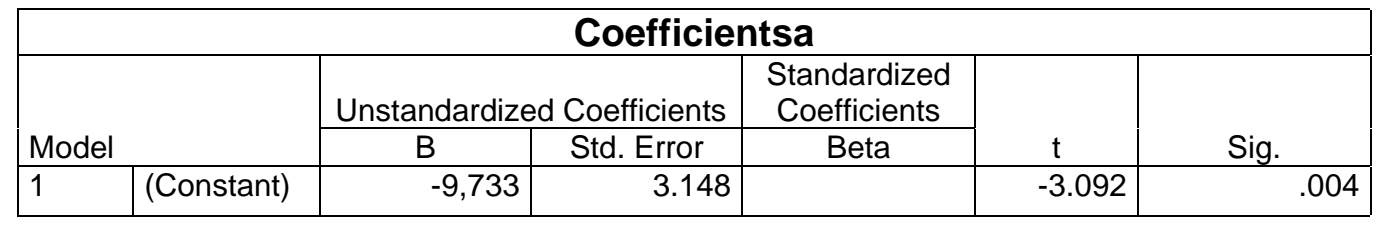


The Effect Of Current Ratio, Debt To Assets Ratio And Working Capital Turnover On Return On Asssets In Plastic Companies And Packing Listed On Indonesia Stock Exchange Dedek Kurniawan Gultom, Bahril Datuk, Mei Indriani

\begin{tabular}{|l|l|r|r|r|r|r|}
\hline & CR & 1,630 & .379 & 1.049 & 4.305 & .000 \\
\cline { 2 - 7 } & DAR & .587 & .342 & .297 & 1,715 & .095 \\
\cline { 2 - 7 } & WCT & .015 & .149 & .018 & .098 & .922 \\
\hline
\end{tabular}

The results of the $t$ statistic in the table above can be explained as follows:

The value for the Current Ratio variable is 4.305 and with $=5 \%$ it is known to be 2.023, thus greater than and the significant value of the Current Ratio is $0.000<0.05$, meaning that from these results it can be concluded that $\mathrm{HO}$ is rejected (Ha is accepted) indicating that there is a significant effect between Current Ratio Ratio to Return 0n Assets in plastic and packaging companies listed on the Indonesia Stock Exchange. $t_{\text {hitung }} t_{\text {tabel }} t_{\text {hitung }} t_{\text {tabel }}$

The value for the Debt to Assets Ratio variable is 1.715 and with $=5 \%$ it is known that it is 2.023 , thus smaller than and the significant value of the Debt to Assets Ratio is $0.095<$ 0.05 , meaning that from these results it can be concluded that $\mathrm{H} 0$ is accepted (Ha is rejected) indicating that it is not there is an effect between Debt to Assets on Return 0n Assets in plastic and packaging companies listed on the Indonesia Stock Exchange. $t_{\text {hitung }} t_{\text {tabel }} t_{\text {hitung }} t_{\text {tabel }}$

The value for the Working Capital Turnover variable is 0.098 and with $=5 \%$ it is known to be 2.023, thus smaller than and the significant value of Working Capital Turnover is 0.992> 0.05 , meaning that from these results it can be concluded that $\mathrm{H} 0$ is accepted (Ha is rejected) indicating that there is no effect between Working Capital Turnover and Working Capital Turnover. Capital Turnover on Return on Assets in plastic and packaging companies listed on the Indonesia Stock Exchange. $t_{\text {hitung }} t_{\text {tabel }} t_{\text {hitung }} t_{\text {tabel }}$

\section{F Test Results (Simultaneous Test)}

The F statistical test was conducted to test whether the independent variable (X) simultaneously had a significant relationship or not to the dependent variable (Y).

Based on the results of data processing with the SPSS version 24.00 program, the following results were obtained:

Table 4.2. F . Test Results

\begin{tabular}{|l|l|r|r|r|r|r|}
\hline \multicolumn{7}{|c|}{ ANOVAa } \\
\hline Model & Sum of Squares & df & Mean Square & F & Sig. \\
\hline 1 & Regression & 26,806 & 3 & 8,935 & 22,430 & $.000 \mathrm{~b}$ \\
\cline { 2 - 7 } & Residual & 13,943 & 35 & .398 & & \\
\cline { 2 - 7 } & Total & 40,749 & 38 & & & \\
\hline \multicolumn{7}{|l|}{ a. Dependent Variable: ROA } \\
\hline \multicolumn{2}{|l}{ b. Predictors: (Constant), WCT, DAR, CR } \\
\hline
\end{tabular}

From the results above, it can be seen that the value is 22,430 with a significant level of 0.000 . While the known value is 3.24. Based on these results, it can be seen that $(22,430>3.24)$ means that it is rejected. So it can be concluded that the variables Current Ratio, Debt To Assets Ratio and working capital turnover have a significant effect on Return On Assets in plastic and packaging companies listed on the Indonesia Stock Exchange. $f_{\text {hitung }} f_{\text {tabel }} f_{\text {hitung }}>\mathrm{f}_{\text {tabel }} \mathrm{H}_{0}$

\section{DISCUSSION}

\section{Effect of Current Ratio on Return On Assets}

Based on the research obtained regarding the effect of the Current Ratio on Return On

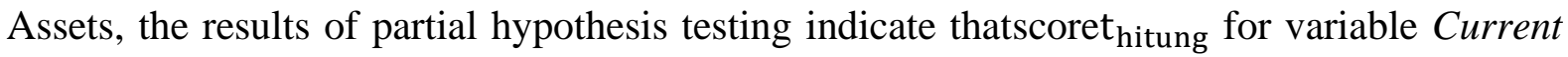

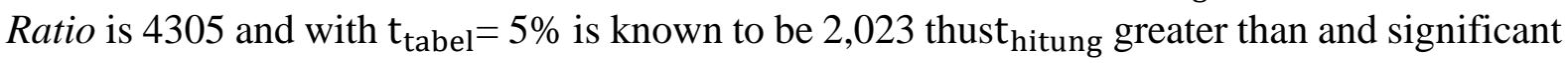


value $\mathrm{t}_{\text {tabel }}$ Current Ratio of $0.000<0.05$ means From these results it can be concluded that $\mathrm{H} 0$ is rejected (Ha is accepted) indicating that there is a significant effect betweenCurrent Ratio on Return 0n Assets in plastic and packaging companies listed on the Indonesia Stock Exchange.

This shows that the Current Ratio is able to increase Return On Assets in plastic and packaging companies listed on the Indonesia Stock Exchange. Where the Current Ratio has increased thenthe company is able or has the funds to meet its short-term obligations that are due soon and the company is able to manage the number of current assets owned by the company so that the company's productivity has increased and the company is able to minimize operating expenses so that the profits owned by the company increase with the increase in profits owned by the company. company, the Return On Assets has increased.

\section{The Effect of Debt to Assets Ratio on Return On Assets}

Based on the research obtained regarding the effect of the Debt to Assets Ratio on

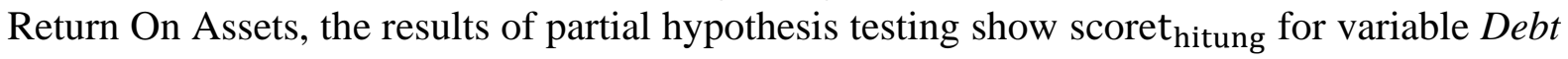
to Assets Ratio is 1.715 and with $t_{\text {tabel }}=5 \%$ is known to be 2,023 thust $t_{\text {hitung }}$ smaller than and significant value $t_{\text {tabel }}$ Debt to Assets Ratio of $0.095<0.05$ meansFrom these results, it can be concluded that $\mathrm{H} 0$ is accepted (Ha is rejected) indicating that there is no effect betweenDebt to Assets on Return 0n Assets in plastic and packaging companies listed on the Indonesia Stock Exchange.

This shows that the Debt to Assets Ratio cannot affect the Return On Assets of plastic and packaging companies listed on the Indonesia Stock Exchange. Wherewith the number of assets owned by the company originating from the company's debt, the company is not able to manage it properly and the interest expense that must be paid is high enough so that the profit generated by the company is less than the maximum, with less than the maximum profit earned by the company, the ROA on the company will also increase. follow less than maximum.

\section{Effect of Working Capital Turnover on Return On Assets}

Based on the research obtained regarding the effect of Working Capital Turnoveron

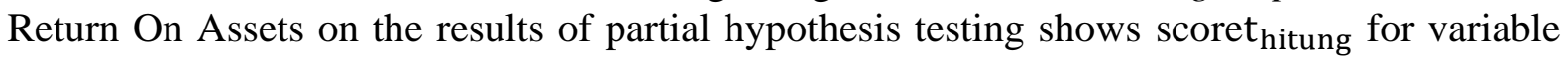
Working Capital Turnoveris 0.098 and with $t_{\text {tabel }}=5 \%$ is known to be 2,023 thust $_{\text {hitung }}$ smaller than and significant value $t_{\text {tabel }}$ Working Capital Turnoverof $0.992>0.05$ meansFrom these results, it can be concluded that $\mathrm{H} 0$ is accepted (Ha is rejected) indicating that there is no effect betweenWorking Capital Turnoveron Return on Assets in plastic and packaging companies listed on the Indonesia Stock Exchange.

This shows thatworking capital turnoverexperienced an increase, it was followed by a decrease in Return On Assets, where the working capital owned by the company was used to meet the company's short-term needs, so that the working capital could not generate productivity and in the end the sales made by the company decreased. by the company has decreased. The decline in profits owned by the company then the company's Return On Assets will decrease.

\section{Effect of Current Ratio, Debt to Assets Ratio and Working Capital Turnover on Return On Assets}


The Effect Of Current Ratio, Debt To Assets Ratio And Working Capital Turnover On Return On Asssets In Plastic Companies And Packing Listed On Indonesia Stock Exchange Dedek Kurniawan Gultom, Bahril Datuk, Mei Indriani

Based on the research obtained regarding the effect of Current Ratio, Debt to Assets Ratio andWorking Capital Turnoveron Return On Assets on the results of hypothesis testing simultaneously showsthat value $\mathrm{f}_{\text {hitung }}$ of 22,430 with a significant level of 0.000 . While the value off tabel is known to be 3.24. Based on these results, it can be seen that $(22,430>3.24)$ means that it is rejected. So it can be concluded that the variables Current Ratio, Debt To Assets Ratio and working capital turnover have a significant effect on Return On Assets in plastic and packaging companies listed on the Indonesia Stock Exchange. $\mathrm{f}_{\text {hitung }}>\mathrm{f}_{\text {tabel }} \mathrm{H}_{0}$

This shows that Current Ratio, Debt to Assets Ratio and Working Capital Turnoverjointly able to increase Return On Assets in plastic and packaging companies listed on the Indonesia Stock Exchange where with the number of current assets and total assets owned by the company originating from company debt and the working capital invested can be managed properly so that the profit generated by the company has increased so that the interest expense used is quite low to be paid or the burden is reduced so that profit net increase and eventually Return On Assets increases.

\section{CONCLUSION}

Based on the data obtained as well as the data analysis that has been carried out and the discussion that has been carried out in the previous chapter, conclusions can be drawn regarding Effect of Current Ratio, Debt to Assets Ratio and Working Capital TurnoverAgainst Return On Assets in Plastic and Packaging Companies Listed on the Indonesia Stock Exchange as follows:

1. Based on research conducted that partially Current Ratio has a significant effect on Return On Assets in plastic and packaging companies listed on the Indonesia Stock Exchange.

2. Based on research conducted that partially Debt to Assets Ratio has no effect on Return On Assets in plastic and packaging companies listed on the Indonesia Stock Exchange.

3. Based on research conducted that partially Working Capital Turnover has no effect on Return On Assets in plastic and packaging companies listed on the Indonesia Stock Exchange.

4. Based on research conducted that simultaneously Current Ratio, Debt to Assets Ratio and Working Capita Turnover jointly have a significant effect on Return On Assets in plastic and packaging companies listed on the Indonesia Stock Exchange.

\section{REFERENCES}

Al-Faruqy, A. F. (2016). Pengaruh Current Ratio, Debt To Equity Ratio dan Total Assets Turn Over Terhadap Return On Investment. Jurnal SCIENTICA, 1(3), 38-55.

Alpi, M. F., \& Gunawan, A. (2018). Pengaruh Current Ratio dan Total Asset Turnover Terhadap Return On Assets Pada Perusahaan Plastik dan Kemasan. Jurnal Riset Akuntansi Aksioma, 17(2), 1-36. http://aksioma.unram.ac.id/index.php/aksioma/article/view/43

Andino Sinaga, R. . (2021). COMMUNICATION PATTERNS OF SOCIAL ASSISTANT PROGRAM FOR THE HARAPAN FAMILY IN THE ACTIVITIES OF FAMILY CAPABILITY IMPROVEMENT MEETINGS (P2K2) BENEFICIARY FAMILY (KPM) BALIGE DISTRICT. International Journal of Educational Review, Law And Social Sciences (IJERLAS), 1(1), 78-87. https://doi.org/10.54443/ijerlas.v1i1.33 


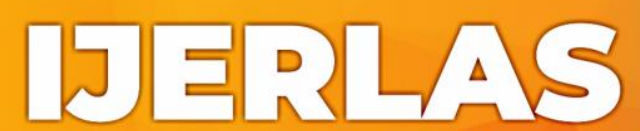

Intentional jounal of Educational Review,

Law And Social Sciences

Ananda, A. N. (2017). Pengaruh Perputaran Modal Kerja dan Perputaran Piutang Terhadap Profitabilitas Pada Perusahaan Pertambangan Sub Sektor Minyak dan Gas Bumi Listing di Bursa Efek Indonesia. JOM FISIP, 4(2), 1-14.

Arseto, D. D., \& Jufrzen, J. (2018). Pengaruh Return On Asset dan Current Ratio Terhadap Dividen Payout Ratio Dengan Firm Size Sebagai Variabel Moderating. Jurnal Ilmiah Magister Manajemen, 1(1), 15-30. https://doi.org/10.30596/maneggio.v1i1.2237.

Brigham, E. F., \& Houston, J. F. (2014). Dasar-Dasar Manajemen Keuangan. Salemba Empat.

Efendi, A. F. W., \& Wibowo, S. S. A. (2017). Pengaruh Debt To Equity Ratio dan Debt to Assets Ratio Terhadap Kinerja Perusahaan Di Sektor Keuangan Yang Terdaftar Di Bursa Efek Indonesia. Journal Of Applied Managerial Accounting, 1(2), 157-163.

Fahmi, I. (2014). Pengantar Manajemen Keuangan. Alfabeta.

Fahmi, Irham. (2014). Manajemen Keuangan Perusahaan dan Pasar Modal. Mitra Wacana Media.

Gultom, D. K. (2017). The Effect of Debt to Equity Ratio, Earning Per Share and Net Profit Margin on Share Price on Textile and Garment Company Listed In Indonesia Stock Exchange. Internasional Conference on Islam Youth Leader (ICIYL).

Gultom, D. K., Manurung, M., \& Sipahutar, R. P. (2020). Pengaruh Current Ratio, Debt To Equity Ratio, Total Asset Turnover terhadap Return on Assets pada Perusahaan Sub Sektor Kosmetik dan Barang Keperluan Rumah Tangga yang Terdaftar di Bursa Efek Indonesia. Jurnal Humaniora: Jurnal Ilmu Sosial, Ekonomi Dan Hukum, 4(1), 1-14.

Hani, S. (2015). Teknik Analisa Laporan Keuangan. UMSU PRESS.

Hani, Syafrida. (2015). Teknik Analisa Laporan Keuangan (Azuar Juliandi (ed.)). UMSU PRESS.

Hery. (2018). Analisis Laporan Keuangan. Grasindo Monoratam.

Jufrizen, J. (2014). Pengaruh Perputarna Kas dan Perputaran Persediaan Terhadap Profitabilitas Pada Perusahaan Plastik dan Kemasan Yang Terdaftar di Bursa Efek Indonesia. Jurnal Ekonomikawan, 14(2), 131-138.

Jufrizen, J., \& Asfa, Q. (2015). Pengaruh Profitabilitas Dan Kebijakan Hutang Terhadap Nilai Perusahaan Pada Perusahaan Farmasi Yang Terdaftar Di Bursa Efek Indonesia Periode 2010-2013. Jurnal Kajian Manajemen Bisnis, 4(2), 1-19.

Jufrizen, J., \& Nasution, M. F. (2016). Pengaruh Return On Assets, Total Assets Turnover, Quick Ratio, Dan Inventory Turnover Terhadap Debt To Assets Ratio Pada Perusahaan 
The Effect Of Current Ratio, Debt To Assets Ratio And Working Capital Turnover On Return On Asssets In Plastic Companies And Packing Listed On Indonesia Stock Exchange

Dedek Kurniawan Gultom, Bahril Datuk, Mei Indriani

Jasa Sub Sektor Perdagangan Besar Barang Produksi Yang Terdaftar Di Bursa Efek Indonesia. Jurnal Riset Akuntansi \& Bisnis, 16(1), 45-70.

Jufrizen, J., Sari, M., Radiman, R., Muslih, M., \& Putri, A. M. (2019). Pengaruh Debt Ratio, Long Term Debt To Equity Ratio dan Kepemilikan Instutisional Terhadap Return On Assets Pada Perusahaan Sub Sektor Makanan dan Minuman Yang Terdaftar Di Bursa Efek Indonesia. Jurnal Manajemen Motivasi, 15(1), 7-18. http://dx.doi.org/10.29406/jmm.v15i1.1376

Juliandi, A, Irfan, I., \& Manurung, S. (2015). Metodelogi Penelitian Bisnis Konsep dan Aplikasi. UMSU PRESS.

Julita, J. (2008). Pengaruh Debt To Equity Ratio Dan Long Term Debt To Equity Ratio Terhadap Profitabilitas Perusahaan. (Studi Kasus Pada Perusahaan Telekomunikasi Yang Terdaftar Di Bursa Efek Indonesia). Kumpulan Jurnal Dosen Universitas Muhammadiyah Sumatera Utara, 7(2), 1-26. http://jurnal.umsu.ac.id/index.php/kumpulandosen/article/view/292

Jumingan. (2017). Analisis Laporan Keuangan. PT. Bumi Aksara.

Kamal, M. B. (2016). Pengaruh Receivabel Turn Over dan Debt to Assest Ratio Terhadap Return On Assets Pada Perusahaan Pertanian Yang Terdaftar di Bursa Efek Indonesia. Jurnal Ilmiah Manajemen Dan Bisnis, 17(2), 68-82.

Kasmir. (2017). Analisis Laporan Keuangan. PT. Raja Grafindo Persada.

Munawir, S. (2010). Analisis Laporan Keuangan. Andi.

Murhadi, W. R. (2013). Analisis Laporan Keuangan Proyeksi dan Valiusai Saham. Salemba Empat.

Muslih, M. (2019). Pengaruh Perputaran Kas dan Likuiditas (Current Ratio) Terhadap Profitabilitas (Return On Assets). Jurnal Krisna: Kumpulan Riset Akuntansi, 11(1), 4759. https://doi.org/10.22225/kr.11.1.1126

Nursalyani, A., Sugeng, W., \& Syaichu, M. (2013). Analisis Current Ratio, Firm Size dan Assets Tangbility Terhadap Return On Assets Pada Perusahaan Pertambangan Yang Terdaftar Di Bursa Efek Indonesia Periode 2008-2011. Jurnal Bisnis Strategi, 2(24), 97127.

Prakosa, K. B. (2014). Pengaruh Profitabilitas, Kepemilikan Keluarga dan Corporate Governance terhadap Penghindaran Pajak di Indonesia. SNA 17 Mataram.

Rambe, M. F. (2013). Pengaruh Struktur Modal Dan Profitabilitas Terhadap Kebijakan Hutang Pada Perusahaan Makanan Dan Minuman Di Indonesia. Jurnal Ilmiah Manajemen Dan Bisnis, 13(1), 85-97. http://jurnal.umsu.ac.id/index.php/mbisnis/article/view/105 
Rambe, M. F., Gunawan, A., Julita, Parlindungan, R., Gultom, D. K., \& Wahyuni, S. F. (2015). Manajemen Keuangan. Perdana Mulya Sarana'.

Riyanto, B. (2010). Dasar-Dasar Pembelanjaan Perusahaan. BPEE-Yogyakarta.

Sanjaya, S., \& Jufrizen, J. (2017). Pegaruh Moderasi Kepemilikan Instutisional Terhadap Determinan Return On Equity di Bursa Efek Indonesia. Jurnal Ilmiah Manajemen Dan Bisnis, 18(2), 189-205.

Siregar, Q. R. (2016). Pengaruh Perputaran Persediaan Dan Perputaran Piutang Terhadap Likuiditas Pada Perusahaan Otomotif Yang Terdaftar Di Bursa Efek Indonesia Priode 2010-2013. Jurnal Ilmiah Manajemen Dan Bisnis, 17(2), 116-127. http://jurnal.umsu.ac.id/index.php/mbisnis/article/view/1000

Sjahrial, D. (2008). Manajemen Keuangan. Mitra Wacana Media.

Sudana, I. M. (2015). Manajemen Keuangan Perusahaan. Salemba Empat.

Sugiyono. (2018). Metode Penelitian Kuantitatif, Kualitatif, dan R\&D. CV. Alfabeta.

Supardi, H., Suratno, \& Suyanto. (2016). Pengaruh Current Ratio, Debt To Assets Ratio,Total Assets Turnover dan Inflasi Terhadap Return On Assets. JIAFE: Jurnal Ilmiah Akuntansi Fakultas Ekonomi, 2(2), 16-27.

Utama, A. C., \& Muid, A. (2014). Pengaruh Current Ratio, Debt Equity Ratio, Debt Asset Ratio, Dan Perputaran Modal Kerja Terhadap Return On Asset Pada Perusahaan Manufaktur Yang Terdaftar Di Bursa Efek Indonesia Tahun 2010-2012. Diponegoro Journal Of Accounting, 3(2), 1-13.

Wahyuni, S. F. (2017). Peran Kepemilikan Institusional Dalam Memoderasi Pengaruh Current Ratio, Debt To Equity Ratio, Total Asset Turnover Dan Inventory Turnover Terhadap Return On Equity Di Bursa Efek Indonesia. Jurnal Riset Finansial Bisnis, 1(2), 147-158. https://ejurnal.id/index.php/jrfb/article/view/107.

Zulkarnaen, Z. (2018). Pengaruh Debt To Assets Ratio Terhadap Return On Assets Pada Perusahaan Asuransi Yang Terdaftar Di Bursa Efek Indonesia. Jurnal Warta Edisis, 56(1), 1-11. 
Volumes 1 No 2 (2021)

The Effect Of Current Ratio, Debt To Assets Ratio And Working Capital Turnover On Return On Asssets In Plastic Companies And Packing Listed On Indonesia Stock Exchange

Dedek Kurniawan Gultom, Bahril Datuk, Mei Indriani 